\title{
Commentary
}

\section{Only the Voice of the Other: Science, Power, and Diversity's Revolt in the Museum-A Manifesto of Sorts}

\author{
W. Warner Wood
}

\begin{abstract}
While the importance of including diverse perspectives in museum programming has received considerable attention in the cultural realm, the same cannot be said for environmental science topics. In science and natural history museums, exhibitions on issues such as global climate change and loss of biodiversity are frequently narrowly defined in relation to an equally narrow perception of what constitutes environmental science. Because the facts of science in museums are still largely told by science curators, the voices of non-scientists are largely absent on such issues. As museum professionals, we must work to ensure that a diversity of perspectives is represented on environmental issues in our museums and on the capacity of our publics to participate in the presentation of environmental topics. We must support the public's collective "power-to" (as John Holloway has termed it) have a voice in environmental programming.
\end{abstract}

[Keywords: Museums, Science, Exhibitions, Diversity, Power. Keywords in italics are derived from the American Folklore Society Ethnographic Thesaurus, a standard nomenclature for the ethnographic disciplines.]

"Only the voice of the other can adequately alert us to plurality and difference," Gerry Kearns observed (1998:404) in discussing the contributions of William Cronon, Donald Worster, Richard White, and Patricia Limerick to what is known as the "New Western History." This "new" history of the western United States that they helped to develop led to an intellectual turn in the 1980s whereby the historiography of the westward expansion of the U.S. (the "frontier") was made more nuanced, complicated, and complicit in the U.S. imperial project.

In the United States, this new interpretive framework created quite a stir when it left the Ivory Tower for "the Nation's museum," the Smithsonian Institution. There, the 1992 opening of the exhibition The West as America: Reinterpreting Images of the Frontier 1820-1920 drew the ire of the Beltway's opinion-makers, some of whom found it to be downright un-American, a view that expressed their self-congratulatory state at the time: basking in the afterglow of the initial "success" of the first Gulf War (Gulliford 1992:201). Some of the good Americans who attended the exhibition, no doubt driven to fits of rage at the audacity of the "lefty" intellectuals who had put it together, actually tore down sections of the exhibition's labels (Kearns 1998:399).

\footnotetext{
* This editorially reviewed contribution was accepted for publication in Museum Anthropology Review on April 21, 2013. The work is licensed under the Creative Commons Attribution 4.0 International License. To view a copy of this license, visit http://creativecommons.org/licenses/by/4.0/.
} 
At my writing of this commentary more than 20 years later, the thought that so much fuss might have been made at the suggestion that the history of the U.S. westward expansion of the United States had come at the expense of people who already occupied those areas (like Native Americans) seems nearly unfathomable. It is now a standard part of the textbook history of the U.nited States that is taught in public schools and museums like the Natural History Museum of Los Angeles County (NHMLAC), where I was once a curator, regularly develop curriculum guides that emphasize these historical "facts." Likewise, the thought that the voices of Native Americans might not be enlisted in telling their own histories at places like the Smithsonian Institution and the NHMLAC is now..., well, beyond the pale. But some kinds of facts are, apparently, more contingent, partial, and contextual than others.

In the 22 years since The West as America exhibition opened, many things have changed (or more accurately, continued to change) in the ways that museums work with diverse communities to develop exhibitions and other programs - with one fairly glaring exception. While we museum professionals seem now, by and large, to accept that cultural histories are plural, political, and (often) rancorous, and that a diversity of perspectives on cultural issues is a good thing, we seldom recognize the same to be true of the natural histories we tell or of the scientific facts that we pepper throughout such exhibitions. To put it differently, it is widely accepted (if somewhat grudgingly in some quarters) that diversity is something we ought to strive for... at least in music, food, clothing, and dance.

But what about science? And I do not mean diversity among the people who are engaged in Western scientific practice (which is an important thing to strive for) nor biological diversity itself, but diversity in the types of science that we hear from, and about, in museums. What about Native American knowledge about the natural world, such as Tlingit understanding of glaciers, as Julie Cruikshank so eloquently describes in her book, Do Glaciers Listen? (2005)? Or feminist scholars/filmmakers engaged in the monumental undertaking of speaking the truth about environmental toxicity and "biocide" to the power of a science establishment that describes environmental "impacts" on the bodies of women and their children (Knopf-Newman 2004, Light and Saraf 1997)? And what about the methodologies of Indian peasant women's forest management practices (Agrawal 2005) or local knowledge of forestry and other practices as described more broadly by James Scott (1998)? Or even, what about the alternative, dare I say, more accurate descriptions of the ways that scientists actually work that have been the focus of Bruno Latour's (1979 [with Woolgar], 1987) widely regarded work? I ask, where are these scientific voices and these versions of science in the public programming of most science and natural history museums? Unfortunately, the answer is: in the vast majority of cases, they are not there at all. We would all be hard-pressed to find these diverse versions of science in our local natural history museum or science center. I could not find them in the NHMLAC when I was a curator there. And we are all the poorer for it. Our lives are richer for the plurality and difference we encounter in the voice of the other at museums - even on scientific issues.

\section{Diversity and Emerging Trends in a Democratized Science}

In museums, telling the stories of Science (the capital " $\mathrm{S}$ " is a deliberate reference to the singular

rational, monolithic, and instrumental Science that science studies researchers such as Latour 
have so thoroughly debunked) is still seen as the purview of scientists and science curators. In the science practices and exhibitions at museums, the voice of the other (what some call "ethnoscience") is almost entirely missing in science exhibits or, more accurately, is not being heard. This must change, and only the plurality of voices of the other that exist and deserve to be heard can adequately represent the diversity of thinking on these issues.

Getting museum scientists to give some space to these perspectives in their exhibitions, however, is not what I suggest needs to happen. The rainbow of diverse voices that could be heard on such topics will always be, when passed though the filter of the curatorial "scientific community," a diluted, insipid, sanitized (and highly censored) version of diversity. Such a strategy would produce a diversity of voices that would not be nearly as diverse as it might easily have been. Where diversity is concerned, it seems to me to be better to do away with the filter altogether. My suggestion, in other words, is not that scientists should start making science exhibitions that include the voice of the other, but that science curators and exhibition developers need to begin to give up their role as science gatekeepers and also give up some of their authority over what counts as a scientific fact and a scientific explanation.

Tim Forsyth (2003) has suggested that "democratizing" science may go a long way toward resolving this issue for science more broadly. Forsyth borrows this line of thinking from the work of Richard Brown (1998). Together, they reason: were science and scientific explanations made more transparent and were the "institutional" bases of scientific practice recognized by scientists themselves, "environmental science [could] be reformed to acknowledge social and political framings... increase[ing] the chance of making explanations more relevant to diverse social groups" (Forsyth 2003:203). Forsyth and Brown are evidently talking about a form of representative democracy where reformed scientists would be better able to represent the interests of their respective constituencies (the rest of the public).

Much of their thinking hinges on the idea that a shift in science away from a "correspondence theory of truth" that frames reality in terms of "universal laws" (that are, in turn, testable as either "true" or "false") and a shift toward institutionalized explanations that recognize the social basis of scientific explanations would act as a catalyst in the transformation of science (2003:213-218). They see this democratized science emerging in several recent trends, including: "science in places" approaches, which emphasize that scientific facts can be region-specific rather than universal truths; "events ecology" approaches, which focus on understanding specific events rather than on empirical facts by combining ideas from non-equilibrium ecology and human historical analyses; and "hybrid science" approaches, which blend social and natural science in order to acknowledge how natural processes and objects are at the same time also the product of social and cultural processes (2003:222-226).

Reforming science and the educational system that trains scientists is, obviously, an even larger project than reforming museum programs, and one that will not likely find its way into the science museum for quite some time, perhaps not for several generations of practicing scientists. Furthermore, recognizing a standard for representation in the democratic government of science that is built from the position that only the voice of the other can adequately alert us to plurality and difference would require a form of direct democracy, not representation of the interests of the public through a reformed science. We do not need a rehabilitated science, even if it is no 
longer using the full force of its power, to represent its singular version of scientific reality for the public. That approach will not get museums past the diluted diversity that would, no doubt, make even a newly reformed science most comfortable.

\section{Museum Lessons from “Dignity's Revolt” in the Jungles of Chiapas, Mexico}

My own thinking on this issue finds its inspiration in the work of John Holloway (1997, 1998, 2002a, 2002b). Flatly stated, it goes something like this: only community members themselves, and diverse community members at that, can make the science museum more diverse. Only the voice of the other can adequately alert us to plurality and difference.

In other words, the vast majority of scientists will never be cajoled into giving up their authority to be the experts on science. For the rest of society, being heard on scientific issues in their museums will come only after their voices are actually present in their museums. How might museum professionals who are committed to diversity, even where "scientific facts" are concerned, help to ensure that this happens? This is where Holloway's ideas, brought to us from the jungles of southern Mexico, provide some guidance.

Much of Holloway's best-known writing has focused on the revolutionary practices of the Zapatistas in Chiapas, Mexico. In a short essay (1997) called "Dignity and the Zapatistas," republished as "Dignity's Revolt" in 1998, he argues that what sets the Zapatista rebellion that began January 4, 1994 (the day the North American Free Trade Agreement went into effect), apart from all previous revolutionary movements in Latin America is that the Zapatistas refused to make it a goal to take control of state government. The Zapatistas have simply asserted their right to their own dignity, and the Zapatista leadership professed to lead only by listening to and serving its community. It is a leadership strategy that the leaders call "mandar obediciendo" (to command obeying) and "preguntando caminamos" (asking we walk), and Holloway finds in it a new principle for revolutionary leadership:

They have emphasized time and time again the importance for them of taking all important decisions through a collective process of discussion, and that the way forward cannot be a question of their imposing their line, but only through opening up spaces for discussion and democratic decisions, in which they would express their view, but their view should count only as one among many. [1998:175]

More recently, Holloway has distilled the essence of their strategy into an entirely new recipe for revolutionary practice, into something that he calls "changing the world without taking power" (2002a, 2002b).

To change the world without taking power, one must begin by asserting one's basic right to work, love, and just live in the world. Holloway characterizes that moment of assertion as the "scream of NO" that insists "negatively" on our "struggle to change the world, to make it a place fit for humans to live in" (2002b). Further, that scream of negative assertion for the right to control our own lives must be made not as part of our efforts to take control but rather as part of 
the dissolution of power. To get to that end point (which will become the starting point of my discussion of how to move towards scientific diversity in science and natural history museums), Holloway reworks Karl Marx's (1973) characterization of the capitalist mode of production as a battle between "power-over" (potestas) and "power-to" (potentia). People, he says, have a basic "power-to-do" that is interrupted or "ruptured" by those who, through various means, control the "means-to-do," those who exert "power-over" the doing of others (2002a:43-46). Those who exert "power-over" control (and sometimes break) the social "flow" of doing, separate those "doing" from what they have "done," and then appropriate the "done" as their own; this is clearly Marx's account of the alienation of labor in commodity production. Holloway argues that we participate in our own subordination (alienation for Marx), treating the stoppage of the social flow of doing as an accomplished fact when, on the contrary, it is a process - and an incomplete one at that! To understand people's separation from their right to "power-to" as a process, Holloway writes, "implies that its course is not pre-determined" and that there is a space for resistance, a space for hope (2002b:5). This is where the world can begin to change, this is the space of "dignity's revolt" in the jungles of Chiapas, Mexico.

\section{Museums as Spaces of Hope for Diversity in the Production of Scientific Facts}

That moment of insight is also the space of hope for diversity's revolt where museums and museum programs, like exhibitions, can begin to change. In the past, I had a tendency to think of the representation of scientific facts in the exhibitions at science and natural history museums as an already accomplished social (scientific) fact. After all, exhibitions are about representation, not production, right? Actually, I have come to see that exhibitions are a part-a core part — of the process of the production of scientific knowledge. That is not to say that museums house the most important laboratories, or employ the "best" scientists with the biggest grants, but rather to say that, (1) for science to happen and have value in society, a large science-literate public that is receptive to and understands the who's, how's, and why's of science must be produced ("educated"); and (2) exhibitions and other museum programs are very important places for that to happen.

Even more important to this discussion, museum exhibitions are a part of the process of the production of scientific knowledge without a predetermined outcome. Science is only a project, albeit a big one, and it is far from complete. Hence, the education and learning about science and the production of scientific facts that transpire through museum public programming are an ongoing part of the process of the production of science itself. Such programs are also a key moment in "power-over" the production of diverse local knowledges about environmental issues. That is, museum exhibitions are one of the important sites where the public's "power-to" produce scientific facts is ruptured, where the social flow of the production of diverse knowledges about environmental issues such as global climate changes and loss of biodiversity is stopped through the "power-over" of orthodox Western Science and scientists who help to produce scientific facts through museum exhibitions. In the same way that a space for change can be identified and acted upon once one recognizes that capitalism is an unfinished project (à la Holloway), recognizing museum exhibitions as part of the yet-to-be-completed process of creating scientific facts opens one's eyes to the possibility that museums hold as a space for the 
public's "power-to" create public programming on science topics and scientific facts using the findings of diverse sciences. ${ }^{2}$

Understanding the production of scientific fact as an unfinished museum program or exhibit provides a space of hope, a space of resistance to instrumental, monolithic, and rational Science in the museum. Just as Holloway suggested that many social movements have a lot to learn from the Zapatistas about how to change the world without taking power (see his more recent work on the Occupy Movement [2010], for example), I suggest that science museum professionals can learn much from them about how to change museums. The point, of course, is not to take control of the museum but to change the museum without taking power. That process begins with a shared insistence that all members of the public have a right to have our diverse sciences heard in the museum. Only the voice of the other can adequately alert us to plurality and difference. This is our expression against the "power-over" of Science-our simultaneous assertion of "powerto"- that marks the beginning of diversity's revolt in the museum.

\section{A Manifesto (of sorts) for the New Museum}

This commentary's inspiration also comes from spaces beyond the jungles of Chiapas, Mexiconamely, from the world of museum professionals and Joseph Veach Noble's widely cited "Museum Manifesto" (1970). As Stephen Weil (1990) suggested in his discussion of the "paradigm shift" that has occurred in the ways museums understand their relationship to their publics, much has changed since Noble laid out the five responsibilities of all museums (see also Gail Anderson's Reinventing the Museum [2004] for a collection of essays, including a reprint of Weil's short piece, that explore this paradigm shift from multiple perspectives). I want here, however, to suggest that we think of the guiding principles of Zapatista political practice in a similar fashion, as two responsibilities of all museums that should guide their practice around the issue of diversity (especially about what constitutes scientific knowledge and practice). For this "manifesto of sorts," those responsibilities are:

1) Mandar Obediciendo ("to command obeying"): Museum administrators and leaders must create platforms for wider, more diverse participation in existing institutional structures such as scientific and collection advisory councils. Museum leadership must listen not only to scientists about scientific issues but also to the diverse perspectives of the world's diverse scientists about the versions of scientific knowledge that have developed historically in a wide variety of cultures across the globe. As Holloway suggests, the Zapatista approach to reaching consensus through "village assemblies" may not in all circumstances be the best "form" for ensuring that leaders obey the wishes of those who they lead, but there are "obvious precedents... [in] deep-rooted traditions of forms of direct democracy" (1998:180). Museums must be led by people who have made "obeying" their communities their modus operandi and who are deeply committed to searching for their museum's most appropriate forms for doing so.

2) Preguntando Caminamos (“asking we walk"): Museum leadership must make it a primary goal and responsibility to create programmatic and administrative spaces that are designed as a means of continuously engaging their communities in the process of telling the museums that the leaders administer what community members think is important. This cannot be accomplished by 
reaching out to community stakeholders for "input" on particular programs or by responding to pressure from the community to solve and put to bed a single issue, but instead must take the form of "a constant probing, a constant asking, a constant searching" of a museum's community for direction on the issues most relevant to society (Holloway 1998:179). For museum professionals, walking with our communities as we simultaneously ask them how we can best serve them as we find our path together is not something to be resolved and moved on from but is an ongoing process of discovery that should lie at the core of museum operations and the development of scientific programming. This association will inevitably be an open-ended process because, in the words of Spain's great poet, Antonio Machado (1875-1939):

Caminante, son tus huellas el camino, y nada más; caminante, no hay camino, se hace camino al andar. Al andar se hace camino, y al volver la vista atrás se ve la senda que nunca se ha de volver a pisar. Caminante, no hay camino-Sino estelas en el mar. [Wanderer, your footsteps are the road, and nothing more; wanderer, there is no road, the road is made by walking. By walking one makes the road, and upon glancing behind one sees the path that never will be trod again. Wanderer, there is no road-Only wakes upon the sea] (from Campos de Castilla, see 2005).

\section{Acknowledgments}

I would like to thank Carlos Alicea for directing me to the work of John Holloway via our reading of the revolutionary and liberatory practice of Che Guevara and Paulo Freire. My thinking here owes much to our short but productive exchange. Some of the ideas discussed here also grow from a paper entitled "The Museum as Triumphal Procession: A Space of Hope for Environmental Justice?" that I presented at Harvard University on October 21, 2006, as part of the workshop: "Conservation, Environmental Justice, and Resource Rights: Tensions and Overlaps." Ajantha Subramanian organized this meeting with the support of the Environmental Leadership Program, the Harvard University Center for the Environment, Harvard University's Political Ecology Working Group, and the Switzer Foundation. My thinking about museums and science has also changed substantially as a consequence of my experience at Harvard. In particular, the challenges posed to me by Drs. Julian Agyeman, Ana Baptista, Jim Igoe, and others in the audience have forced me to consider how museums are much more than social institutions where the "facts" of science are exhibited. Thanks to you all, I am beginning to come to terms with the fact that museums are a principal locus for the production of scientific knowledge.

\section{Notes}

1. The opening passages of Karen Mary Davalos' (2003) critique of representations of Mexican Americans in museums throughout the U.S. notwithstanding, museums like the NHMLAC, which she writes about having visited as a young girl, have dramatically changed their portrayal of Mexican-American histories and have endeavored to change the ways that they work with Mexican-American communities. The NHMLAC's renovated California History Hall, "Becoming L.A.," which openned in 2013, is a case in point. 
2. Imagine, for example, a science museum that gave equal time to the environmental knowledges of Aboriginal/Indigenous peoples outside of anthropology exhibition halls in a fashion similar to ethnobotanist and author Gary Paul Nabhan's $(1982,1985,1997)$ widely regarded writing about the people and plants of the U.S. desert Southwest.

\section{References Cited}

Anderson, Gail, ed.

2004 Reinventing the Museum: Historical and Contemporary Perspectives on the Paradigm Shift. Lanham, MD: Altamira Press.

Agrawal, Arun

2005 Environmentality: Technologies of Government and the Making of Subjects. Durham, NC: Duke University Press.

Brown, Richard H.

1998 Toward a Democratic Science: Scientific Narration and Civic Communication. New Haven, CT: Yale University Press.

Cruikshank, Julie

2005 Do Glaciers Listen? Local Knowledge, Colonial Encounters, and Social Imagination. Seattle: University of Washington Press.

Davalos, Karen Mary

2003 Exhibiting Mestizaje: Mexican (American) Museums in the Diaspora. Albuquerque: University of New Mexico Press.

Forsyth, Tim

2003 Critical Political Ecology: The Politics of Environmental Science. New York: Routledge.

Gulliford, Andrew

1992 Review of The West as America: Reinterpreting Images of the Frontier, 1820-1920" (exhibition). William H. Truettner, curator, National Museum of American Art, Smithsonian Institution, Washington, DC. Journal of American History 79(1): 199-208. http://dx.doi.org/10.2307/2078477

Holloway, John 
1997 Dignity and the Zapatistas. Common Sense: Journal of the Edinburgh Conference of Socialist Economists 22(December):38-42.

1998 Dignity's Revolt. In Zapatista!: Reinventing Revolution in Mexico. John Holloway and Eloína Peláez, eds. Pp. 159-198. London: Pluto Press.

2002a Change the World Without Taking Power: The Meaning of Revolution Today. London: Pluto Press.

2002b Twelve Theses on Changing the World without Taking Power. The Commoner Online 4 (May). http://www.churchland.org.za/wp-content/uploads/2013/02/holloway-12theses.pdf, accessed July 10, 2014.

2010 Crack Capitalism. London: Pluto Press.

Kearns, Gerry

1998 The Virtuous Circle of Facts and Values in the New Western History. Annals of the Association of American Geographers 88 (3):377-409. http://dx.doi.org/10.1111/0004$\underline{5608.00106}$

Knopf-Newman, Marcy Jane

2004 Public Eyes: Investigating the Causes of Breast Cancer. In New Perspectives on Environmental Justice: Gender, Sexuality, and Activism. Rachel Stein, ed. Pp. 161-176. New Brunswick, NJ: Rutgers University Press.

Latour, Bruno

1987 Science in Action: How to Follow Scientists and Engineers Through Society. Cambridge, MA: Harvard University Press.

Latour, Bruno, and Steve Woolgar

1979 Laboratory Life: The Social Construction of Scientific Facts. Sage Library of Social Research, 80. Beverly Hills, CA: Sage Publications.

Light, Allie, and Irving Saraf, dirs.

1997 Rachel's Daughters: Searching for the Causes of Breast Cancer. 107 minutes. Women Make Movies. New York.

Machado, Antonio

2005 Campos De Castillo = The Landscape Of Castile, Mary G. Berg and Dennis Maloney, trans. Buffalo, NY: White Pine Press. 
Marx, Karl

1973 Grundrisse: Foundations of the Critique of Political Economy, Martin Nicolaus trans. New York: Random House.

Nabhan, Gary Paul

1982 The Desert Smells Like Rain: A Naturalist in Papago Country. San Francisco: North Point Press.

1985 Gathering the Desert. Tucson: University of Arizona Press.

1997 Cultures of Habitat: On Nature, Culture, and Story. Washington, DC: Counterpoint.

Noble, Joseph Veach

1970 Museum Manifesto. Museum News 48(8):16-20.

Scott, James C.

1998 Seeing Like a State: How Certain Schemes to Improve the Human Condition have Failed. New Haven, CT: Yale University Press.

Weil, Stephen E.

1990 Rethinking the Museum: An Emerging New Paradigm. Museum News 69(2):56-61.

W. Warner Wood is an Associate Professor in the Department of Anthropology at the University of Wisconsin-Milwaukee, where he also coordinates the Graduate Certificate Program in Museum Studies and serves as an adjunct curator at the Milwaukee Public Museum. He is the author of many works, including the book Made In Mexico: Zapotec Weavers and the Global Ethnic Art Market (Bloomington: Indiana University Press, 2008). He has served in a range of museum leadership roles, including as Assistant Curator of Latin American Anthropology at the Los Angles County Museum of Natural History and as Director of the Centennial Museum at the University of Texas at El Paso.

http://dx.doi.org/10.14434/mar.v8i1.3255 